\title{
A preliminary cost-benefit analysis for inclusion of caucasian clover in new dairy pasture
}

\author{
G.H. TAYLOR ${ }^{1}$ and R.N. WATSON ${ }^{2}$ \\ ${ }^{1}$ Agriculture New Zealand, PO Box 1068, Hamilton \\ ${ }^{2}$ AgResearch, Ruakura Agricultural Research Centre, Private Bag 3123, Hamilton
}

\begin{abstract}
In a coastal Bay of Plenty trial, ryegrass pasture containing the rhizomatous legume caucasian clover (CC), provided advantages from late spring to autumn in total herbage yield and legume content in the $2^{\text {nd }}$ to $4^{\text {th }}$ years, compared with a ryegrasswhite clover pasture. Sub-optimal pasture supply and quality, in summer and autumn especially, can limit seasonal milk production potential. Thus, greater milk yield from pasture which includes CC can be derived from greater dry matter on offer to cows, and also through improved forage quality afforded by increased legume content. CC is slower to establish than white clover (WC) and may be favoured by spring rather than autumn sowing. The extra costs for successfully establishing CC in pasture and the milk yield potential from greater herbage yields and legume content were used to determine the level and rate of economic benefit from its inclusion in dairy pasture. Depending on the assumptions made, $\mathrm{CC}$ was calculated to recover net establishment costs in the 4th year, with a net present value over 10 years of $\$ 789$, or a $35 \%$ internal rate of return. At this level of return use of $\mathrm{CC}$ in pasture renewal would be an attractive longerterm option. A number of considerations, which need to be taken into account, include as yet unestablished benefits for $\mathrm{CC}$ on heavier or moister soils which are less compromising to $\mathrm{WC}$ persistence, the slow establishment of $\mathrm{CC}$, the effects of different methods of establishment and longer-term effects of pasture pests on its performance potential.
\end{abstract}

Keywords: caucasian clover, cost-benefit, coastal Bay of Plenty, dairy pasture, Lolium perenne, Trifolium ambiguum, Trifolium repens

\section{Introduction}

Pasture production and utilisation in situ underpins the competitive advantage enjoyed by New Zealand dairying (Penno 1997) and is dominated by ryegrass (Lolium perenne) (RG)/white clover (Trifolium repens) (WC) pasture. Special purpose crops such as maize (Zea mays), brassicas or lucerne (Medicago sativa) have been used to supplement pasture in times of feed deficits, usually during winter or during summer/autumn drought. Nitrogen $(\mathrm{N})$ is also commonly used to bolster pasture production. With the exception of $\mathrm{N}$ used strategically, the net returns from using alternative production systems are either seasonally dependent or at best marginal.

Reliance on pasture for dairy, cattle and sheep production depends on an efficiently performing legume component to input cheap $\mathrm{N}$, and as a means of improving forage quality (Caradus et al. 1995; Harris et al. 1997). Pasture clover content is especially advantageous in summer/autumn when WC could be expected to compensate for the declining yield and forage quality of RG.

Surface spreading of WC from stolons exposes the plant to potentially lethal soil surface temperatures in summer (Brock \& Kim 1994; Watson et al. 1996a) while pasture pests, in particular plant parasitic nematodes, can drastically reduce potential WC yields and $\mathrm{N}$-fixation, and delay recovery after drought (Watson et al. 1994). Caucasian clover (Trifolium ambiguum) (CC) is a perennial pasture legume with many of the forage attributes of WC, but which spreads underground from rhizomes instead of surface stolons. It retains a tap-root longer than WC does after establishment and has a reputation for persistence under adverse conditions (Allan \& Keoghan 1994; Virgona $\&$ Dear 1996). Thus CC provides a possible means of managing the susceptibility of WC to summer drought and nematode attack. CC is slower than WC to establish good ground cover because it develops its underground rhizome network in the first year. CC is also winter dormant and seedlings sown in autumn may remain small and vulnerable until September/October. This means that $\mathrm{CC}$ plants are susceptible to grass or weed competition during the establishment period (Hill \& Hoveland 1993; Hill \& Mulcahy 1995), and that investment in successful establishment is critical to achieving early returns.

In a trial in the coastal Bay of Plenty (BOP), a pasture containing $\mathrm{CC}$ produced $9 \%$ more herbage annually by the 2 nd year than pasture containing WC (Watson et al. 1996b). The greatest advantages came 
from extra clover production during the summer and autumn. In the third year, yield increases began in spring, with $50 \%$ clover content in herbage and 50\% greater herbage yield than RG/WC pasture during summer and early autumn (Watson et al. 1997). This is consistent with the desired legume content of $50 \%$, which will maximise milk yields from pasture (Harris et al. 1997). Thus CC shows the potential to improve both pasture yield and legume content at a time which is critical for maintaining milk flow, and the potential therefore to improve cash returns for dairy farmers. This paper investigates likely cash returns from $\mathrm{CC}$ in dairy pasture, based on results from the first four years of trials in the coastal Bay of Plenty.

\section{Methods}

\section{Experimental}

The establishment and performance of pasture plots of $\mathrm{CC}$ and WC pastures with RG over the first three seasons were presented by Watson et al. (1996b; 1997). Briefly, pure swards of cv. Grasslands Kopu WC and Endura CC were sown as pelleted, inoculated seed (equivalent to 3 and $5 \mathrm{~kg} / \mathrm{ha}$ of bare seed respectively) into a prepared seed-bed after maize cropping in September 1994 using a roller drill. Light grazing of the pastures began in February 1995 and cv. Yatsyn RG was undersown in July 1995 . The main plots were approximately 0.125 ha (4 replicates in randomised blocks) and these were grazed as a common pasture by dairy cattle. Grazing was usually at monthly intervals but this was extended during summer drought and during winter. Pasture production was assessed from 5 $\times 5 \mathrm{~m}$ mown sub-plots placed within the grazed plots. In the 1996-98 seasons strips $10 \mathrm{~m}$ long were also mown from each main plot area to determine herbage yields from grazed pasture (Watson et al. 1997). Herbage dissection samples were taken from these areas before each harvest, and from the mown plots on a seasonal basis. Plots were mown immediately before the paddock was grazed. Some of the pasture samples taken from the catcher for dry matter (DM) determinations, and some ryegrass and clover samples from herbage dissections, were retained for later determination of crude protein (CP) and metabolisable energy (ME) by near infra-red (NIR) analysis.

\section{Cost-benefit analysis}

\section{Economic analysis}

This cost-benefit analysis looks at the benefit of adding $\mathrm{CC}$ to a ryegrass-based pasture mix compared with establishing a conventional RG/WC pasture. As no full dairying systems with established CC exist, the analysis is somewhat simplistic and based on a number of assumptions. The pasture production figures used are those from the BOP trial described.

\section{Cultural regime}

This analysis is based on the successful establishment techniques used in the BOP trial, which included spring sowing (Anon. undated; Taylor 1998). It was assumed pasture is sown as part of a pasture renewal programme. Only costs incurred above those normally expected in a regrassing programme have been included in the analysis. The cultural regime is illustrated in Figure 1.

Because of the desirability of using a crop rotation to reduce pest/disease challenges to clover establishment and for ease of comparison, it was assumed both the $\mathrm{CC}$ and WC treatments went through a summer crop. This means the spring sowing of CC pasture is 6 months later than for $\mathrm{RG} / \mathrm{WC}$, requiring the use of a winter crop, such as annual ryegrass, to follow the summer crop. In the BOP trial, pure clover species were sown in spring and ryegrass was undersown the following winter. In this situation summer grass (Digitaria sanguinalis) invaded and provided similar competition to that which RG might provide. Therefore, RG at a reduced sowing rate of $10 \mathrm{~kg} / \mathrm{ha}$ was assumed for this analysis. Similarly, a local ecotype of WC established in the $\mathrm{CC}$ plots in the BOP trials. WC was therefore included with the $\mathrm{CC}$ since it can out-produce $\mathrm{CC}$ in the first year, establishes early ground cover, contributes to the suppression of weeds and may produce increased $\mathrm{DM}$ in the first year. Use of a winter-active WC cultivar could provide some complementary production when $\mathrm{CC}$ is dormant. Sowing rates are shown in Table 1. On the assumption that sowing a winter-active WC cultivar with $\mathrm{CC}$ would provide parity in winter activity with a RG/WC sward, only those periods when CC exceeded WC production have been used in the cost-benefit analysis.

Figure 1 Cultural regime for new ryegrass-white clover (RG/WC) or ryegrass/caucasian clover (RG/CC) pasture establishment.

\begin{tabular}{|l|llllllllllllllllll|}
\hline RG/WC & \multicolumn{1}{l}{ SUMMER CROP } & & \multicolumn{1}{l}{ NEW GRASS } \\
Month & O & N & D & J & F & M & A & M & J & J & A & S & O & N & D & J & F & M \\
RG/CC & SUMMER CROP & & & WINTER CROP & & & & & NEW GRASS & & & \\
\hline
\end{tabular}




\section{Results and discussion}

\section{Production benefits}

To ascertain the production benefits of $\mathrm{CC}$, the total herbage accumulation of RG/WC was compared with that of $\mathrm{RG} / \mathrm{CC}$ plots where no other treatments were imposed.

The superiority of RG with $\mathrm{CC}$ is evident from late spring to early autumn (Figure 2). Advantages from $\mathrm{CC}$ are lost in winter because of a slightly reduced ryegrass content and inactivity by CC. In autumn 1997 and 1998 differential yields were reduced by the large contribution from summer grass going to seed on WC plots (Watson et al. 1998).

The decline in the DM difference between the RG/ $\mathrm{CC}$ and RG/WC pasture over time masked a widening gap as shown in relative yields (Table 2). Very high pasture and legume vigour following establishment after cropping coincided with a moist summer in year 1 , followed by insect and nematode pest build-up in year 3 and a major drought in year 4 , causing a progressive reduction in annual pasture yields (Watson et al. 1997; 1998). By autumn 1998 WC had virtually disappeared from the pasture.

Over seven samplings taken, $\mathrm{CP}$ and $\mathrm{ME}$ levels respectively were $11 \%$ and $7 \%$ greater in pasture from $\mathrm{CC}$ plots compared with pasture from WC plots (Table 3). Of the two forage values, ME is considered to be the first limiting factor in pasture forage (Kolver \& Muller 1998), although ME and CP were generally co-related in the BOP pasture. Greatest differences were in summer and autumn when pasture clover content varied most widely. Clover not only improves forage quality but adds to voluntary feed
Table 1 Assumed sowing rates for ryegrass-white clover (RG/ WC) and ryegrass/caucasian clover (RG/CC) pastures.

\begin{tabular}{|c|c|c|c|}
\hline \multirow[t]{2}{*}{ Sowing rate $(\mathrm{kg} / \mathrm{ha})$} & \multicolumn{2}{|c|}{----- Treatment ------ } & \multirow[t]{2}{*}{$\$ / \mathrm{kg} \mathrm{seed}^{1}$} \\
\hline & RG/WC & RG/CC & \\
\hline Ryegrass & 20 & 10 & 4 \\
\hline White clover & 4 & 2 & 9 \\
\hline Caucasian clover & 0 & 4 & 23 \\
\hline
\end{tabular}

1 seed price for CC includes inoculation which is essential for nodulation

Table 2 Spring to autumn yield advantages by ryegrass/ caucasian clover (RG/CC) pasture compared with ryegrass-white clover (RG/WC) pasture from 1995/96$1997 / 98$.

\begin{tabular}{lrrr}
\hline & Year 1 & Year 2 & Year 3 \\
\hline Yield difference (kg DM/ha) & 1856 & 1528 & 1417 \\
Relative yield (CC/WC) & 115 & 119 & 122 \\
\hline
\end{tabular}

Table 3 Whole pasture crude protein and metabolisable energy levels from plots of ryegrass with caucasian (CC) or white clover (WC).

\begin{tabular}{lccccccccc}
\hline Month/year & & $12 / 96$ & $2 / 97$ & $4 / 97$ & $6 / 97$ & $12 / 97$ & $4 / 98$ & $6 / 98$ & mean \\
\hline Protein\% & CC & 20.7 & 21.3 & 23.2 & 18.8 & 19.9 & 24.7 & 18.9 & 21.1 \\
& WC & 17.3 & 16.5 & 21.2 & 19.5 & 20.3 & 20.4 & 17.5 & 19.0 \\
ME (MJ/kg DM) & CC & 10.2 & 10.9 & 11.3 & 10.7 & 10.5 & 10.9 & 9.7 & 10.6 \\
& WC & 9.8 & 9.7 & 10.2 & 10.2 & 10.2 & 9.9 & 9.5 & 9.9 \\
\hline
\end{tabular}

Figure 2 Growth rate differences of ryegrass/caucasian clover pasture relative to ryegrass/white clover pasture over years 2 to 4 after establishment in September 1994.

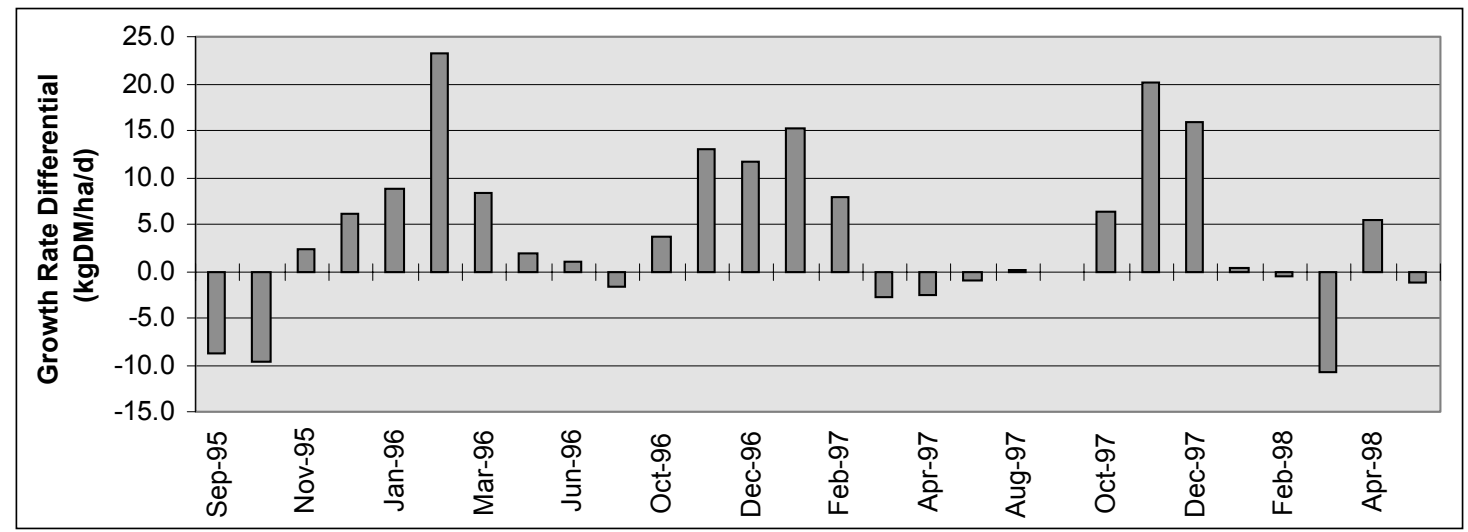


Milk production benefits from the use of $\mathrm{CC}$ in dairy pasture will depend on the farmer making management changes to maximise the utilisation of the extra feed provided by CC. Modelling the year 3 data through the UDDER dairy farm simulation programme (Larcombe 1990) demonstrates this (Table 4). When $\mathrm{CC}$ was introduced to the farm and no other changes were made, production increased by only $51 \mathrm{~kg}$ milksolids (MS)/ha compared with an increase of 151 $\mathrm{kg}$ MS/ha when stocking rate and drying off dates were changed to maximise utilisation. The important changes to reach this level of performance were an increase in stocking rate of 0.5 cows/ha and drying off 2 weeks

Table 4 Simulated milk yield after inclusion of caucasian clover (CC) in pasture, using unchanged management or advanced management with extra cows and 2 weeks longer milking.

\begin{tabular}{lcccc}
\hline & $\begin{array}{c}\text { Unchanged management } \\
\text { Production } \\
\text { (kg MS/ha) }\end{array}$ & $\begin{array}{c}\text { Stocking rate } \\
\text { (Cows/ha) }\end{array}$ & $\begin{array}{c}\text { Advanced management } \\
\text { Production } \\
\text { (kg MS/ha) }\end{array}$ & $\begin{array}{c}\text { Stocking rate } \\
\text { (Cows/ha) }\end{array}$ \\
\hline RG/WC & 822 & 2.7 & 855 & 2.5 \\
RG/WC/CC & 873 & 2.7 & 1,006 & 3.0 \\
\hline
\end{tabular}

later into late May. Shifting the calving date was not viable because of the low winter activity of CC.

For further analysis it was assumed additional DM production is converted into MS at the rate $1 \mathrm{~kg} \mathrm{MS} / 14$ $\mathrm{kg}$ DM. For the year 3 data this equates to an estimated increase in milk production of $109 \mathrm{~kg}$ MS/ha. This is intermediate between the unchanged and advanced management systems and reflects the potential of CC on the average farm.

\section{Cost-benefit analysis}

It was assumed that the profit or loss incurred through the use of the summer crop, as a regrassing step, was equal for both treatments. Other costs are based on industry prices in the Waikato and common farm practice for pasture establishment.

For spring sowing (Table 5a) the post-tax net present value (NPV) ${ }^{1}$ after 3 years of investing in $\mathrm{CC}$ is $\$ 17$, discounted at $6 \%{ }^{2}$. This represents an internal rate of return (IRR) $)^{3}$ of $8 \%$. By the end of year 4, the investment made in $\mathrm{CC}$ had been recovered. Whether a 4-year payback period for regrassing is acceptable to dairy farmers has not

Table 5 Cost-benefit analysis for sowing caucasian clover (CC) in (a) spring or (b) autumn compared with conventional ryegrass-white clover (RG/WC) regrassing in autumn.

\begin{tabular}{|c|c|c|c|c|c|c|c|c|c|}
\hline & & \multicolumn{4}{|c|}{$\longrightarrow$ (a)Spring sown -} & \multicolumn{4}{|c|}{ (b)Autumn sown } \\
\hline & & Yr 1 & Yr 2 & Yr 3 & Yr4 & Yr 1 & Yr 2 & Yr 3 & Yr 4 \\
\hline $\begin{array}{l}\text { Benefits } \\
\text { Increased income } \\
\text { Decreased costs }\end{array}$ & $\begin{array}{l}\text { Milk solids at } \$ 3.55 \\
\text { - Transitional cropping } \\
\text { - Caucasian clover DM } \\
\text { Nil }\end{array}$ & 1268 & 471 & 387 & 359 & $\begin{array}{c}0 \\
471\end{array}$ & 387 & 359 & $359^{1}$ \\
\hline Total Benefits & & 1268 & 471 & 387 & 359 & 471 & 387 & 359 & 359 \\
\hline $\begin{array}{l}\text { Costs } \\
\text { Decreased income } \\
\text { Increased costs }\end{array}$ & $\begin{array}{l}\text { Summer pasture losses } \\
\text { Winter pasture losses } \\
\text { Winter crop } \\
\text { - annual ryegrass seed } \\
\text { Caucasian clover sowing } \\
\text { - increased seed cost } \\
\text { - power harrow - } 1 \text { pass } \\
\text { - roll - 1pass } \\
\text { - roller seed drill } \\
\text { - broadleaf weed spray } \\
\text { - starter fertiliser } \\
\text { Variable milk prodn costs }\end{array}$ & $\begin{array}{r}1521 \\
60 \\
\\
50 \\
100 \\
70 \\
70 \\
60 \\
100 \\
0\end{array}$ & 113 & 113 & 113 & $\begin{array}{r}50 \\
70 \\
60 \\
0\end{array}$ & 113 & 113 & 113 \\
\hline Total Costs & & 2031 & 113 & 113 & 113 & 814 & 113 & 113 & 113 \\
\hline $\begin{array}{l}\text { Net benefit } \\
\text { Taxation }\end{array}$ & Pre-tax & $\begin{array}{l}-764 \\
-252\end{array}$ & $\begin{array}{l}358 \\
118\end{array}$ & $\begin{array}{r}274 \\
91\end{array}$ & $\begin{array}{r}246 \\
81\end{array}$ & $\begin{array}{l}-343 \\
-113\end{array}$ & $\begin{array}{r}274 \\
91\end{array}$ & $\begin{array}{r}246 \\
81\end{array}$ & $\begin{array}{r}246 \\
81\end{array}$ \\
\hline Net Benefit & Post-tax & -512 & 240 & 184 & 165 & -230 & 184 & 165 & 165 \\
\hline
\end{tabular}

1 Assumed to be same as for year 3

1. NPV discounts cashflows resulting from an investment over time allowing comparison between investments in today's dollars.

2. Risk free bank deposit rate as at May 98 and adjusted for tax.

3. IRR gives the average earning power of money invested resulting from subsequent cashflows, i.e., what interest rate will this investment earn. 
been determined. If increased MS income of around $\$ 350 /$ ha could be reliably forecast out to year 10 , the IRR climbs to $35 \%$ with an NPV of $\$ 789$. This is a respectable rate of return over time and highlights the principle that decisions on regrassing need to be taken with a view to the long term.

If additional production were to drop by $15 \%, \mathrm{CC}$ would be unprofitable at year 4 (Table 6). This may happen through poor establishment technique or a lack of management ability to harvest the additional DM grown. Profitability is also dependent on payout. This means $\mathrm{CC}$ requires competent management to reap the potential benefits.

Table 6 Sensitivity of net present value (\$) to changes in additional milk production gained from caucasian clover production and to milksolids payout.

\begin{tabular}{lcccccccc}
\hline & \multicolumn{8}{c}{ Added production (kg MS/ha) owing to CC } \\
& & $-45 \%$ & $-30 \%$ & $-15 \%$ & $0 \%$ & $15 \%$ & $30 \%$ & $45 \%$ \\
\hline & $\mathbf{3 . 9 5}$ & -195 & -103 & -12 & 80 & 171 & 263 & 354 \\
Payout & $\mathbf{3 . 7 5}$ & -208 & -123 & -37 & 48 & 133 & 219 & 304 \\
(\$/kg MS) & $\mathbf{3 . 5 5}$ & -221 & -142 & -63 & 17 & 96 & 175 & 254 \\
& $\mathbf{3 . 3 5}$ & -234 & -161 & -88 & -15 & 58 & 131 & 204 \\
& $\mathbf{3 . 1 5}$ & -247 & -180 & -114 & -47 & 20 & 87 & 154 \\
\hline
\end{tabular}

These potential benefits are also relatively sensitive to small changes in the net cost of establishment. The most variable expenses, assuming successful establishment of the crops and pastures, are the gains made from winter cropping and the losses made through reduced summer pasture production in the first year. The other factors individually have little effect. New pasture was expected to produce about half that of an annual ryegrass crop which generally will yield about $10 \mathrm{t} \mathrm{DM} / \mathrm{ha}$ between planting and late September. Likewise, between October and March the new WC pasture, which had been planted for 7 months, was expected to produce twice as much as the $\mathrm{CC}$ pasture which was planted in mid October. After March, production was expected to be similar. Sensitivity analysis shows that a decrease in yield of $500 \mathrm{~kg} \mathrm{DM} / \mathrm{ha}$ (10\%) from the winter crop or a $500 \mathrm{~kg} \mathrm{DM} / \mathrm{ha} \mathrm{(8 \% )}$

Table 7 Sensitivity of net present value (\$) to changes in DM yield from winter crop and summer pasture preparatory to establishing caucasian clover in new pasture.

\begin{tabular}{lcrrrrr}
\hline & & \multicolumn{6}{c}{ Winter Crop } & Benefits (kg DM/ha) \\
& & 4000 & 4500 & 5000 & 5500 & 6000 \\
\hline & $\mathbf{5 0 0 0}$ & 17 & 101 & 186 & 271 & 356 \\
Summer Pasture & $\mathbf{5 5 0 0}$ & -68 & 17 & 101 & 186 & 271 \\
Losses & $\mathbf{6 0 0 0}$ & -153 & -68 & 17 & 101 & 186 \\
(kg DM/ha) & $\mathbf{6 5 0 0}$ & -238 & -153 & -68 & 17 & 101 \\
& $\mathbf{7 0 0 0}$ & -323 & -238 & -153 & -68 & 17 \\
\hline
\end{tabular}

increase in lost summer production would both make CC unprofitable at year 4 (Table 7).

Other issues that should also be considered in individual cases include: any increase in the value of land as a result of obtaining higher production from it, the capital costs involved in adjusting the management system and payment incentives for shoulder production. Given that there are only 4 years of production data available, the question of persistence of CC must also be addressed when assessing risk.

This analysis has assumed an early-October sowing date for $\mathrm{CC}$, as there are no establishment data in northern regions to support the viability of autumn sowing. It may be that autumn sowing is feasible, especially if CC is sown early enough to gain sufficient plant size to survive winter competition. This could potentially mean some benefit could be gained from additional CC DM in year 1 which would increase returns. Alternatively, if establishment is not strong, it may take a longer period (2-4 years) for $\mathrm{CC}$ to make a significant contribution to extra production, which would mean a reduced return on the investment made in regrassing.

A cost-benefit analysis representing the inclusion of CC in autumn-established pasture (represented in Table 5b) is based on the key assumption that CC will establish strongly in the first autumn and achieve the same levels of production in the following spring as spring-sown plots from the BOP trials which had been established for 12 months before they had provided any additional DM (in year 2). Winter pasture production is assumed to be $2500 \mathrm{~kg} \mathrm{DM} / \mathrm{ha}$ less for CC than for autumn-sown RG/WC pasture because $\mathrm{CC}$ pastures are sown half the usual rate of RG. Under this scenario the payback is in year 3, a year sooner than for spring-sown CC. At this point an NPV of $\$ 229$ is generated, providing an IRR of $56 \%$. Under these assumptions autumn-sown $\mathrm{CC}$ appears more profitable than spring-sown CC. However, it is important to note autumn sowing of CC has not been widely proven and the profitability of autumn sown CC is very dependent on successful establishment. It is not the intent of this paper to recommend autumn sowing of $\mathrm{CC}$.

\section{Conclusions}

The vulnerability of CC during establishment is well documented. Current recommendations to USA growers go as far as to state CC should be planted only into a prepared seed-bed, in spring and in the absence of companion species (Taylor 1998). Trials under dryland dairying on light soils in the BOP, using these "best" principles for establishment, have shown that $\mathrm{CC}$ has good potential for adding to summer pasture production 
and forage quality from year 2, and for greatly superior persistence to WC by year 4 . The performance potential of CC in heavier more traditional dairying soils such as the Waikato is not known, although even under these favourable dairying conditions pasture WC content is usually insufficient to achieve potential summer milk flows from pasture (Harris 1997). The cost benefit analysis developed using production data from BOP trials shows worthwhile returns from $\mathrm{CC}$ when treated as a medium- to longer-term investment under the assumptions used. Because of the simplistic nature of these assumptions, the use of CC needs to be carefully evaluated on a case-by-case basis. The following factors from the BOP study are seen as important in achieving the full early potential from $\mathrm{CC}$ :

- sowing after cropping to ensure reduced pest and disease burdens at planting;

- shallow $(10 \mathrm{~mm})$ sowing into a well-consolidated seed-bed;

- use and optimum treatment of efficient nodulating bacteria to maximise early nodulation;

- adequate sowing rate to maximise early leaf cover and spread of nodulating bacteria;

- early spring sowing to establish a good root system before onset of summer drought and to ensure a strong healthy plant going into the first winter;

- sowing as pure species using a roller drill, with later undersowing of grass to minimise plant competition until rhizome establishment;

- light grazing during the first six months to maximise leaf growth and root/rhizome development;

- use of adequate fertiliser to realise the growth potential of the plant.

\section{REFERENCES}

Allan, B.E.; Keoghan, J.M. 1994. More persistent legumes and grasses for oversown tussock country. Proceedings of the New Zealand Grassland Association 56: 143-148.

Anon. 1997. Economic survey of factory supply dairy farmers 1996-97. Statistics Section, Livestock Improvement Corporation Ltd. Private Bag 3016, Hamilton, New Zealand.

Anon. Undated. Endura Kura clover: management package. Kimihia Research Centre, Wrightson Seeds Ltd., Christchurch.

Brock, J.L.; Kim, M.C. 1994. Influence of the stolon/ soil interface and plant morphology on the survival of white clover during severe drought stress. Proceedings of the New Zealand Grassland Association 56: 187-191.
Caradus, J.R.; Woodfield, D.R.; Stewart, A.V. 1995. Overview and vision for white clover. pp. 1-6. In: Woodfield, D.R. (ed.) White clover: New Zealand's Competitive Edge. Agronomy Society of New Zealand Special Publication No. 11/ Grassland Research and Practice Series No. 6.

Harris, S.L. 1997. The performance of clover in dairy pastures. Dairy Farming Annual 49: 142-149.

Harris, S.T.; Clark, D.A.; Auldist, C.D.; Waugh, C.D.; Laboyrie, P.G. 1997. Optimum white clover content for dairy pastures. Proceedings of the New Zealand Grassland Association 59: 29-33.

Hill, M.J.; Hoveland, C.S. 1993. Defoliation and moisture stress influence competition between endophyte-free tall fescue and white clover, birdsfoot trefoil and Caucasian clover. Australian journal of agricultural research 44: 1135-1145.

Hill, M.J.; Mulcahy, C. 1995. Seedling vigour and rhizome development in Trifolium ambiguum $M$. Bieb.(Caucasian clover) as affected by density of companion grasses, fertility, drought and defoliation in the first year. Australian journal of agricultural research 46: 807-819.

Kolver E.S.; Muller, L.D. 1998. Performance and intake of high producing Holstein cows consuming pasture or a total mixed ration. Journal of dairy science 81: 1403-1411.

Larcombe, M. 1990. UDDER: a desktop dairy farm for extension and research. Proceedings of the $7^{\text {th }}$ Seminar - Dairy Cattle Society of New Zealand Veterinary Association, Hamilton, 22-25 May 1990: 152-152.

Penno, J. 1997. Stick to grassland basics and survive. Dairy exporter (February): 18-19.

Taylor, N.L. 1998. Kura clover. New Crop FactSHEET. Centre for New Crops and Plant Products. Purdue University. > www.http://newcrop.hort.purdue.edu/ newcrop/cropfactsheets/KuraClover.html <

Virgona J.M.; Dear, B.S. 1996. Comparative performance of Caucasian clover (Trifolium ambiguum cv Monaro) after 11 years under low-input conditions in south-eastern Australia. New Zealand journal of agricultural research 39: 245-253.

Watson, R.N.; Bell, N.L.; Neville, F.J.; Harris, S.L. 1994. Improving pasture sustainability by reducing the impact of clover nematodes. pp. 83-85. In: Pankhurst, C.E. (ed.) Soil Biota: Management in Sustainable Farming Ecosystems. CSIRO, Australia.

Watson, R.N.; Harris, S.L.; Bell, N.L.; Neville, F.J. 1996a. Deferred grazing to enhance white clover content in pastures (abstract). p. 154. In: Woodfield, D.R. (ed.) White clover: New Zealand's Competitive Edge. Agronomy Society of New Zealand Special 
Publication No. 11/Grassland Research and Practice Series No. 6.

Watson, R.N.; Neville, F.J.; Bell, N.L.; Harris, S.L. 1996b. Caucasian clover as a pasture legume for dryland dairying in coastal Bay of Plenty. Proceedings of the New Zealand Grassland Association 58: 183-188.

Watson, R.N., Neville, F.J., Bell, N.L.; Harris, S.L. 1997. Caucasian clover for improving summer production in northern regions of New Zealand. Proceedings of the New Zealand Grassland Association 59: 227-232.

Watson R.N.; Neville, F.J.; Bell, N.L. 1998. Caucasian clover performance during a year of severe drought. Proceedings of the New Zealand Grassland Association 60: 119-125. 